\title{
INTRODUCTION TO SYMPOSIUM ON JOOST PAUWELYN, “THE RULE OF LAW WITHOUT THE RULE OF LAWYERS? WHY INVESTMENT ARBITRATORS ARE FROM MARS, TRADE ADJUDICATORS ARE FROM VENUS"
}

\author{
Donald McRae*
}

Investor-State Dispute Settlement (ISDS), a matter on which scholars have had diverging views, has captured public attention, particularly in Europe, with proposals by the European Union to change the ad hoc arbitration normally found in bilateral investment treaties to a more court-like system with an appellate process. Joost Pauwelyn's creative and provocative paper ${ }^{1}$ has added a new dimension to this debate. Focusing on who decides disputes, Pauwelyn brings to light some interesting and perhaps nonintuitive data on the differences between World Trade Organization (WTO) panelists and investment arbitrators. The paper also contributes to the continuing debate over the relationship between the disciplines of trade and investment law and the legitimacy of ISDS more generally.

The lively commentary that follows in this edition of AJIL Unbound from scholars and practitioners concerned with trade and investment is a tribute to Pauwelyn's imaginative work. The idea that WTO dispute settlement can be seen as more efficient or effective than investment arbitration is queried; the WTO process itself is seen as open to question, particularly in view of the length of time disputes are now taking; the different roles played by the WTO Secretariat and the International Centre for the Settlement of Investment Disputes (ICSID) Secretariat is seen as a better reason for the differences; and to the extent that the WTO system can be seen as less subject to criticism the existence of an appellate process in the WTO is seen as a potential reason.

Rather than traversing the points raised in the essays that follow, I will focus my comments in this introductory essay on two principal areas. First, while the paper deals with contemporary differences between the two dispute settlement systems, not enough attention is given to the origins of the two systems. Differences in origin can explain in part why WTO panel members and investment arbitrators have different backgrounds and experience. Second, there is an implicit assumption in the paper that it is possible to compare arbitrators against some kind of ideal model for persons who adjudicate trade and investment disputes. A final comment raises questions about assumptions of convergence between the fields of trade and investment.

* Hyman Soloway Chair in Business and Trade Law, University of Ottawa, Faculty of Law.

Originally published online 13 April 2016.

1 Joost Pauwelyn, The Rule of Law Without the Rule of Lawyers? Why Investment Arbitrators Are from Mars, Trade Adjudicators from Venus, 109 AJIL 761 (2015). 


\section{The Origins of Dispute Settlement in Trade and Investment}

The assumption that there should be some similarity between the persons who decide trade disputes and those who decide investment disputes overlooks the differences in the origins of the two dispute settlement processes. The selection of persons to sit on trade cases and of those to sit on investment disputes is in part a function of the history of the two forms of dispute settlement. WTO dispute settlement is an institutionalized, more streamlined version of the General Agreement on Tariffs and Trade (GATT) system, and the ambivalence in GATT between conciliatory and mediatory roles and that of adjudication has continued into the WTO. The Dispute Settlement Understanding (DSU) embraced adjudication while retaining to a large extent the language and process of conciliation and mediation, and it retained the predominance of trade diplomats in WTO dispute settlement.

Investment arbitration has a quite different history. Rather than evolving organically as GATT/WTO dispute settlement has done, it arose out of the transplanting of a state-to-state arbitration model, adapted to allow investors to bring claims directly against states - what is sometimes referred to as a mixed form of arbitration. After it was established, the process generally lay unused for some time. When it began to be used, investors and states looked to those who had had experience with international arbitral disputes to sit on investor-state arbitrations. Since state-to-state arbitration was spasmodic, there was no core pool of international arbitrators for those disputes. But there was such a pool of arbitrators available in the field of international commercial arbitration, and that is where parties went initially to find arbitrators. And ICSID had probably assumed that most of its disputes would be disputes under investment contracts rather than disputes under bilateral investment treaties. As time went on, individuals other than international commercial arbitrators were added to the pool of those deciding such disputes including individuals who had substantive experience in investment law or in public international law more generally.

Thus, the differences in the pools from which each dispute settlement system drew were different because of their history. GATT initially chose trade diplomats because GATT dispute settlement was not perceived as an adjudicatory function and lawyers were not welcome in GAT'T in any event. Investment arbitration chose commercial arbitrators because that seemed the closest model. It was commercial arbitrators who developed the investment arbitration system in its early days both practically and intellectually and they did so by trying to see investment arbitration in commercial arbitration terms. In order to fit within a commercial arbitration model, investment arbitration was seen as arbitration without privity. ${ }^{2}$ It is not clear that public international lawyers would have felt the need to explain why individuals could sue states before an arbitral tribunal — they were simply granted that right by treaty. In the same way international human rights lawyers have never felt a need to find a rationale to explain why individuals could take states to an international tribunal rather than relying on domestic courts or diplomatic protection - they were granted that right by treaty.

In short, the differences today between who become WTO panelists and who become investment arbitrators are deeply rooted in the history of the two forms of adjudication.

\section{Is There a Model of an "Tdeal" Arbitrator?}

There is an implicit assumption in Pauwelyn's paper about what constitutes an ideal arbitrator. The paper uses a number of value-laden terms- "low key technocrats" to describe WTO panel members and "elite private lawyers and legal academics" to describe ICSID arbitrators. The former are said often to have little experience

${ }^{2}$ Jan Paulsson, Arbitration Without Privity, 10 ICSID FOREIGN INV. L.J. 232 (1995). 
and the latter to have much more experience and expertise. But such language obscures the central question of what skills are required of those who act as adjudicators in either the trade or the investment fields.

GAT'T saw the need to have on panels those who understood GATT and understood the needs of the trading regime and the interests of Contracting Parties. WTO panel members are faced primarily with contested views about the application of the relevant WTO agreement and less frequently about contested facts. Thus, expertise in how trade regulation operates in fact and in the way the WTO agreements should be applied is what is needed in a trade adjudicator. Bringing in "elite lawyers" or professors with expertise in public international law is simply not going to help unless they have expertise in trade policy or trade regulation and the relevant WTO agreements. Thus, the pools of individuals from whom trade and investment arbitrators are chosen have historically been quite separate-public international lawyers knew little about international trade law although by contrast trade lawyers are becoming more aware of public international law and its relevance to the WTO agreements. ${ }^{3}$

The investment arbitration field can be analyzed in a similar way. Commercial arbitrators were sought out because they knew something about how arbitration functions, not because they were experts in investment law. So what skills did they bring-how to conduct an arbitration, how to deal with complex damages questions, and how to interpret contracts. And some of this is key for investment disputes. Unlike WTO disputes, which deal with few procedural matters, investment arbitrations are rich in procedural questions, document production, bifurcation of proceedings, cross-examination of witnesses and experts. Thus, experience in other forms of arbitration where such matters are common, as they often are in commercial arbitration, was essential to the effective functioning of investment arbitration.

But what was generally lacking in investment arbitrators was a background in public international law and in the detailed obligations under bilateral investment agreements, and perhaps the broader political context in which investment regulation occurs. Contract interpretation does not operate within the interpretative framework of the Vienna Convention on the Law of Treaties. Investment treaties were thus seen as contracts rather than treaties and some of the jurisprudence that comes from investment disputes reflects this. And when investment arbitrators began to embrace the Vienna Convention their approach was hardly like that of the WTO Appellate Body. Article 31 was a frequently cited mantra, not to provide the basis for a precise methodology, but to enable the tribunal to make interpretative choices based on a subjective reading of the text couched as an application of the Vienna Convention, or of a perceived single but overriding purpose of investment agreements to promote investment.

But, would bringing in public international lawyers because they might have a better understanding of how the Vienna Convention should be applied, or an understanding of how most favored nation clauses developed, or an historical perspective on the application of expropriation under international law make anything different, or better? Pauwelyn suggests that investment arbitration today is dealing more with general laws or regulations, ${ }^{4}$ which suggests the need for a different type of arbitrator, but one could say the same thing about trade disputes, which directly focus on the ability of governments to regulate and make policy choices.

All of this gets back to a fundamental question. What are the characteristics of the perfect arbitrator? And is the perfect arbitrator for ICSID cases the same as the perfect panel member for WTO disputes? In any event, whether in investment or trade someone who has the experience in all that is required is highly unlikely to exist.

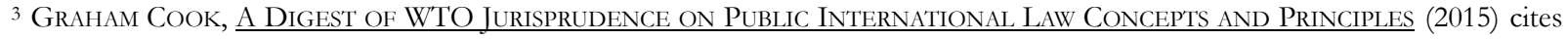
over two hundred panel or Appellate Body reports or WTO arbitrator's awards where public international law rules or principles have been discussed.

${ }^{4}$ Pauwelyn, supra note 1 , at 768. 
As a result, whatever their backgrounds, arbitrators in investment disputes and WTO panel members have in fact had to engage in much learning on the job.

What this also shows is that WTO panel members have some of the expertise necessary for resolving WTO disputes and ICSID arbitrators have some of the expertise necessary for resolving investment disputes. A fortunate mix of three panel members or three ICSID arbitrators may result in a collective set of the necessary skills. And of course with the volume of cases in the trade and investment fields over the years this has led to a larger pool of both arbitrators and panel members with a more comprehensive set of skills than those who sat on the first cases.

How, then, does one address Pauwelyn's conclusion that the low key technocrats have been much more successful in fulfilling their role in settling WTO disputes than have the so-called elite lawyers and legal academic arbitrators dealing with investment disputes? The argument for this appears to be that ICSID dispute settlement is under fire while WTO dispute settlement is not. I wonder if this can be seriously sustained. As is pointed out in a number of essays, both systems have gone through periods of criticism, questioning and legitimacy crises. And the current public controversy over investor-state dispute settlement has more to do with questioning whether there is any role for ISDS at all rather than querying whether the right people are deciding investment disputes notwithstanding the fact that the European Union has chosen to try to deal with the controversy by focusing on the process for the appointment of arbitrators. At the same time the panel appointment process for the WTO has also been the subject of criticism and of proposals for review.

What sort of conclusions can be drawn from all of this? Generally, I find that the characterization of WTO panels members as low key technocrats and ICSID arbitrators as elite private lawyers or legal academics to be descriptively unhelpful in trying to understand why certain individuals are appointed to resolve disputes under each system. They have different skills and those skills are in many respects the skills that are appropriate for what they have to do. The history of the forms of dispute settlement and the institutional processes surrounding them make them different and I wonder if they are really comparable.

As a result, I query the characterization of WTO panelists as less experienced and ICSID arbitrators as having more expertise. Experience and expertise in what? Surely WTO panel members are better equipped to deal with what they have to decide than ICSID arbitrators would be if they had to decide trade disputes. The ideal arbitrator for WTO disputes is simply different from the ideal arbitrator in ICSID disputes. The assumption of lawyers that legal skills are always what are needed for dispute settlement simply may not be correct.

\section{The Relevance of Convergence}

There is a broader question behind Pauwelyn's analysis. The convergence between trade law and investment law, in his view, makes the differences between WTO panelists and investment arbitration arbitrators "striking." 5 I wonder here if the notion of convergence is being made to carry too much baggage.

The case for convergence can be made in a number of respects, ${ }^{6}$ but I am not sure that the fact that investment and trade cases can be brought on the same set of facts necessarily means that arbitrators with the same qualifications should hear them. The fact that a set of facts may raise both trade and law of the sea issues does not suggest a need for members of the Law of the Sea Tribunal to have the same qualifications as WTO panelists. Nor does the fact that some trade and investment disciplines seek to achieve the same goal of nondiscrimination necessarily imply that arbitrators with the same skills and experience should be deciding them. The

${ }^{5} \underline{I d}$. at 803.

6 JÜRGEN KURTZ, THE WTO AND INTERNATIONAL INVESTMENT LAW: CONVERGING SYSTEMS (2016). 
fact that trade in goods and cross-border investment are linked does not necessarily mean that dispute settlement processes in respect of the two must be the same.

An understanding of the similarities and differences in the potential scope of application of provisions on nondiscrimination is certainly desirable, but the extent of the need for the "cross-fertilization," to which Pauwelyn refers, ${ }^{7}$ depends on the nature of the disciplines that have been imposed and what they seek to achieve. If the legal standards are similar and the context of their application comparable, then there may be a case for harmonization and convergence. But that is about the substance of the law being applied, not the mechanisms for resolving disputes or the qualifications of adjudicators.

The following essays provide a critique of Pauwelyn's paper, some further context, as well as alternative views on the difference between WTO panelists and investment arbitrators.

Giorgio Sacerdoti queries whether statistical information about panelists and arbitrators can provide a useful basis to explain the different functioning of legal institutions, or that the differences in the success of the two systems are as stark as suggested. ${ }^{8}$ He points out that the WTO process was also criticized in the past and that there are problems facing the WTO process today, in particular delays well beyond those contemplated in the DSU. He queries the characterization of WTO panel members as "predominantly low-key diplomats from developing countries."

Gabrielle Marceau, Catherine Quinn, and Juan Pablo Moya Hoyos draw attention to the history of government employees on GATT panels, the remuneration of WTO panel members and geographical diversity and representativeness on WTO panels including how the system provides opportunities for developing country members to be appointed to panels. ${ }^{9}$ They also discuss the role of the WTO Secretariat and the extent to which there is cross-fertilization between the jurisprudence of investment arbitration and WTO panel decisions and the extent to which interactions between the two systems might occur in the future.

Catherine Rogers focuses on issues of representation and inclusiveness and how the WTO appointment process at both the panel and the Appellate Body level can exclude those with expertise. ${ }^{10}$ The role of the Secretariat in the WTO comes in for particular comment. She further points out that the complaints made about ISDS today are similar to those made against the WTO previously but which have now become muted. She queries whether ISDS has become the new focus for "antiglobalization angst." She also suggests that some of the reaction to ISDS is because of the size of the awards and "despised parties"-multinational corporations.

Freya Baetens suggests that in many cases the differences between WTO panelists and ICSID arbitrators and the different incentives for their appointment can be explained, and she queries some of the statistics used by Pauwelyn that seem to be inconsistent with other studies. ${ }^{11}$ She also questions whether the alleged differences are the reason for one body of adjudicators to be seen as more successful than the other. She, too, focuses on the role of the WTO Secretariat. Ultimately, she considers whether the appointments processes respond to the needs of each system, but the public perception of those systems differ. Reform of the WTO panel appointment system and an ISDS appellate process would be important ways to change unfavorable perceptions of the two systems.

\footnotetext{
7 Pauwelyn, supra note 1, at 803.

${ }^{8}$ Giorgio Sacerdoti, Panelists, Arbitrators, Judges: A Response to Joost Pawnelyn, 109 AJIL UnBound 283. (2016).

${ }_{9}^{9}$ Gabrielle Marceau, Catherine Quinn, and Juan Pablo Moya Hoyos, Judging from Venus: A Response to Joost Pawnelyn, 109 AJIL UnBOUnD 288 (2016).

${ }^{10}$ Catherine A. Rogers, Apparent Dichotomies, Covert Similarities: A Response to Joost Paunvelyn, 109 AJIL UnBOund 294 (2016).

${ }^{11}$ Freya Baetens, The Rule of Law or the Perception of the Beholder? Why Investment Arbitrators are under Fire and Trade Adjudicators are not: $A$ Response to Joost Pawwelyn, 109 AJIL UnBOUND 302 (2016).
} 
Robert Howse asks the broader question of how much dispute settlement culture matters for the legitimacy of an international regime. ${ }^{12}$ Pauwelyn's view that it does matter suggests that the European Union's proposal for a court and appellate process for investment disputes is on the right track. He focuses, too, on the WTO Appellate Body and the WTO Secretariat, querying Pauwelyn's view that there is little difference between panel members and Appellate Body members. In his view, investment law, unlike W'TO law, lacks an independent interpretative community that can mediate between the concerns of outsider stakeholders and the development of investment law jurisprudence.

12 Robert Howse, Venus, Mars, and Brussels: Legitimacy and Dispute Settlement Culture in Investment Law and WTO Law: A Response to Joost Pannelyn, 109 AJIL UnBound 309 (2016). 